\title{
Assessment of Drug use Pattern in Paediatric Department of a Tertiary Care Hospital
}

\author{
Debbie Mathai ${ }^{1}$, Saumiya Salim ${ }^{1}$, Ram Hinge1 , Nandakumar UP', Juno J. Joel ${ }^{1, *}$, Vijaya Shenoy ${ }^{2}$ \\ 'Department of Pharmacy Practice, NGSM Institute of Pharmaceutical Sciences, Nitte (Deemed to be University), Paneer, Deralakatte, Mangaluru, Karnataka, INDIA. \\ ${ }^{2}$ Department of Paediatrics, Justice KS Hegde Charitable Hospital, Nitte (Deemed to be University) Paneer, Deralakatte, Mangaluru, Karnataka, INDIA.
}

\begin{abstract}
Background: Prescription analysis is an essential means to monitor drug use and ascertain the rationality of prescriptions. This study was conducted to assess the drug usage pattern and identify the possible drug-drug interaction in the paediatric ward of the tertiary care hospital. Methods: A prospective observational study was conducted in the paediatric department to analyse the prescriptions using WHO core prescribing indicators and also to identify the possible drug-drug interactions. The study was conducted for a period of 6 months. The drug therapy details were collected and documented in a specially designed data collection form. Descriptive statistics were applied to analyse the data. Results: Among 340 prescriptions studied, 1091 drugs were prescribed. The most commonly prescribed drug class was antibiotics (25.93\%), followed by antipyretic and anti-inflammatory agents (16.68\%). Acetaminophen was the frequently prescribed drug $(14.57 \%)$, followed by amoxicillin-clavulanic acid $(12.09 \%)$. The average number of drugs prescribed per prescription was 3.2. $24.11 \%$ of drugs were prescribed as generics. The percentage of antibiotics and injections prescribed was $68.52 \%$ and $25.58 \%$,
\end{abstract}

respectively. The percentage of drugs that are prescribed from EDL was $88.52 \%$. One hundred forty-three drug interactions were identified from the prescriptions, of which the majority were found to be moderate in severity $(86.01 \%)$. Conclusion: The study observed increased use of antibiotics when associated with WHO core prescribing indicators. It also observed a majority of moderate drug-drug interactions.

Key words: Paediatrics, Prescribing indicators, Prescription pattern, WHO core indicators, Drug-drug interactions, Antibiotics.

\section{Correspondence}

Dr. Juno J Joel,

Assistant Professor, Department of Pharmacy Practice, NGSM Institute of Pharmaceutical Sciences, NITTE (Deemed to be University), Paneer, Deralakatte, Mangaluru-575018, Karnataka, INDIA.

Phone: +919480470727

Email: junojoel@nitte.edu.in

DOI: 10.5530/jyp.2020.12.68

\section{INTRODUCTION}

"Paediatrics is a discipline of medical science which is concerned with the physical, mental and social health of children from birth to young adulthood". ${ }^{1}$ Children constitute $40 \%$ of the Indian population and thus, their health status is an important aspect. Although the paediatric patients are high in numbers, there is less ongoing research in the department of paediatrics. Hence, there should be rational therapy prescribing guidelines for the paediatric and continuous research should be carried out to update the course of therapy. ${ }^{2}$ Prescribing pattern studies are effective tools to analyse drug use. ${ }^{3}$ Rational prescription is well-reflected by the World Health Organization (WHO) definition stating "Rational use of medicines requires that patients receive medication appropriate to their clinical needs, in doses that meet their requirements, for an adequate period and at the lowest cost to them and their community"., ${ }^{4} \mathrm{WHO}$ has formulated a set of core prescribing indicators, which measure the performance of prescribers and monitor judicious and rational prescribing practices. The assessment of WHO core prescribing indicators help to improvise the prescribing pattern and even to minimize the cost burden on the patient. ${ }^{3}$ The core prescribing indicators listed in the manual includes an average number of drugs per prescription, percentage of generic drugs, antibiotics and injections prescribed and a number of drugs prescribed in the essential drug list. ${ }^{6,7}$ WHO has proposed a reference value for all these parameters; even though it is empirical, this helps in the assessment and interpretation of the study results. Drug-drug interaction is one of the major drug-related problems leading to the failure of therapy. ${ }^{8}$ Polypharmacy, irrational use of drugs and dispensing errors can be identified through prescribing pattern studies. ${ }^{9}$ Paediatric prescription is more complex than adults because a prescription is given according to weight and some drugs are contraindicated in paediatric age groups due to their physiological peculiarities. Rational prescribing in the paediatrics can reduce the wastage of resources, prevent adverse events, prevent the potential drug-drug interaction and reduce the incidence of treatment failure and antibiotic resistance. Pharmacists are in a suitable place to assess the rational prescribing pattern of the therapy. ${ }^{10}$ Hence, the present study focuses on the assessment of prescription patterns in the paediatric population and to compare with the standard WHO core prescribing indicators. Since minimal studies on drug-drug interactions are done among paediatric population, the study also aims to assess the possible drug-drug interactions.

\section{MATERIALS AND METHODS}

A prospective observational study was carried out in the paediatric department of a multispecialty teaching hospital, located in Dakshina Kannada, Mangaluru. The study was conducted for a period of six months (September 2018 -February 2019). Institutional Ethics Committee permission (IEC Ref No: NGSMIPS/IEC/03/2018-19) was taken before initiating the study. Both the out-patients and in-patients who visited the paediatric department were included in the study. Critically ill patients and those who came for immunization were excluded from the study. A suitable patient data collection form was prepared, which includes patient details such as age, gender, hospital number, complaints on

This is an open access article distributed under the terms of the Creative Commons Attribution-NonCommercial-ShareAlike 4.0 License, which allows others to remix, tweak, and build upon the work non-commercially, as long as the author is credited and the new creations are licensed under the identical terms. 
admission, diagnosis, drug therapy details such as brand/generic name, dose, frequency and route of administration. World health organization (WHO) core prescribing indicators were used for the assessment of drug therapy.

\section{Assessment of WHO core prescribing indicators}

- The average number of drugs per encounter was calculated by dividing the total number of different drug products prescribed by the number of encounters surveyed.

- Percentage of drugs prescribed by generic name was determined by dividing the number of drugs prescribed by generic name by the total number of drugs prescribed, multiplied by 100 .

- Percentage of encounters with an antibiotic prescribed was calculated by dividing the number of patient encounters during which an antibiotic was prescribed by the total number of encounters surveyed, multiplied by 100 .

- Percentage of encounters with an injection prescribed was calculated by dividing the number of patient encounters during which an injection was prescribed by the total number of encounters surveyed, multiplied by 100 .

- The percentage of drugs prescribed from an essential drug list (EDL) was determined by dividing the number of products prescribed from EDL of the hospital by the total number of drugs prescribed, multiplied by $100 .^{4}$

\section{Prescribing pattern assessment}

- Various types of drugs prescribed among the study population were categorized as per the category of the drug. Thus the commonly prescribed drugs among the various categories are identified.

Possible potential drug interactions in the prescriptions were analysed with the aid of Stockley's drug interactions textbook and drug information software (up-to-date). Descriptive statistics were applied to obtain the frequency and percentage of the variables in the study.

\section{RESULTS}

A total of 340 patients were included in the study as per the inclusion criteria. Table 1 shows the age-wise distribution. Male patients 187(55\%) outnumbered female patients 153(45\%). Based on age groups, the patients were categorized into five and the majority belonged to the age group of 1 month-2years (40.29\%) followed by 2-6 years (32.35\%). A total of 491 clinical conditions were observed among 340 patients. The most common clinical condition was fever, which was present in 132 patients (26.88\%) followed by Upper Respiratory Tract Infections in 114 patients (23.22\%) and Lower Respiratory Tract Infections in 103 patients (21\%).

A total of 1091 drugs were prescribed among 340 patients. The drug class that was commonly prescribed were antibiotics (25.9\%) followed by antipyretic and anti-inflammatory agents (16.68\%), anti-asthmatics

Table 1: Age and gender-wise distribution.

\begin{tabular}{cccc}
\hline \multirow{2}{*}{ Age group } & \multicolumn{2}{c}{ Gender } & Total frequency \\
\cline { 2 - 3 } & $\begin{array}{c}\text { Male } \\
\boldsymbol{n = 1 8 7 , \%}\end{array}$ & $\begin{array}{c}\text { Female } \\
\boldsymbol{n = 1 5 3 , \%}\end{array}$ & \\
\hline <1 month (Neonate) & 0 & $2(0.58)$ & $2(0.58)$ \\
1 month-2 years (Infant) & $83(24.41)$ & $54(15.88)$ & $137(40.29)$ \\
2-6 years (Young child) & $53(15.58)$ & $57(16.76)$ & $110(32.35)$ \\
6-12years (Child) & $39(11.47)$ & $31(10.54)$ & $70(20.58)$ \\
12-18years (Adolescent) & $12(3.53)$ & $9(2.64)$ & $21(6.17)$ \\
\hline
\end{tabular}

Table 2: Drug class and drugs prescribed to the paediatric population.

\begin{tabular}{|c|c|c|c|}
\hline Drug Class & Drugs & $\begin{array}{c}\text { Frequency } \\
(n=1091)\end{array}$ & $\begin{array}{c}\text { Percentage } \\
\text { (\%) }\end{array}$ \\
\hline \multirow{17}{*}{$\begin{array}{l}\text { Antibiotics } \\
(\mathrm{n}=283)\end{array}$} & $\begin{array}{l}\text { Amoxycillin- } \\
\text { Clavulanic acid }\end{array}$ & 132 & 12.10 \\
\hline & Amikacin & 32 & 2.93 \\
\hline & Azithromycin & 27 & 2.47 \\
\hline & Cefixime & 26 & 2.39 \\
\hline & Ceftriaxone & 23 & 2.11 \\
\hline & Cefotaxime & 20 & 1.84 \\
\hline & Mupirocin & 4 & 0.36 \\
\hline & Cephalexin & 3 & 0.27 \\
\hline & Clarithromycin & 3 & 0.27 \\
\hline & Fusidic acid & 3 & 0.27 \\
\hline & Ciprofloxacin & 3 & 0.27 \\
\hline & Tobramycin & 2 & 0.18 \\
\hline & Erythromycin & 2 & 0.18 \\
\hline & Doxycycline & 1 & 0.09 \\
\hline & Gentamycin & 1 & 0.09 \\
\hline & Vancomycin & 1 & 0.09 \\
\hline & & 283 & 25.94 \\
\hline \multirow{6}{*}{$\begin{array}{c}\text { Analgesics } \\
\text { and Anti-pyretics } \\
\qquad(n=182)\end{array}$} & Acetaminophen & 159 & 14.57 \\
\hline & Mefenamic acid & 11 & 1.01 \\
\hline & Ibuprofen & 5 & 0.46 \\
\hline & Tramadol & 4 & 0.36 \\
\hline & Diclofenac & 3 & 0.27 \\
\hline & & 182 & 16.68 \\
\hline \multirow{5}{*}{$\begin{array}{l}\text { Anti-asthmatics } \\
\quad(n=75)\end{array}$} & Levosalbutamol & 30 & 2.75 \\
\hline & Budesonide & 28 & 2.57 \\
\hline & Salbutamol & 15 & 1.37 \\
\hline & Mometasone & 2 & 0.18 \\
\hline & & 75 & 6.87 \\
\hline \multirow{5}{*}{$\begin{array}{l}\text { Anti allergics } \\
\quad(n=71)\end{array}$} & Chlorpheniramine & 30 & 2.75 \\
\hline & Hydroxyzine & 20 & 1.83 \\
\hline & Levocetrizine & 17 & 1.55 \\
\hline & Dexomethorphan & 4 & 0.37 \\
\hline & & 71 & 6.50 \\
\hline \multirow{4}{*}{$\begin{array}{l}\text { Anti-ulcer } \\
(n=64)\end{array}$} & Ranitidine & 49 & 4.50 \\
\hline & Pantoprazole & 8 & 0.73 \\
\hline & Lansoprazole & 7 & 0.64 \\
\hline & & 64 & 5.87 \\
\hline \multirow{3}{*}{$\begin{array}{l}\text { Anti-emetics } \\
\quad(n=54)\end{array}$} & Ondansetron & 49 & 4.50 \\
\hline & Domperidone & 5 & 0.46 \\
\hline & & 54 & 4.96 \\
\hline \multirow{4}{*}{$\begin{array}{l}\text { Corticosteroids } \\
\qquad(n=30)\end{array}$} & Prednisolone & 25 & 2.30 \\
\hline & Hydrocortisone & 4 & 0.36 \\
\hline & Fluticasone & 1 & 0.09 \\
\hline & & 30 & 2.75 \\
\hline $\begin{array}{c}\text { Anti-Epileptics } \\
\quad(n=25)\end{array}$ & Clonazepam & 9 & 0.82 \\
\hline
\end{tabular}


(6.87\%) and anti-allergic (6.50\%).The most commonly prescribed drug was paracetamol 159(14.57\%), followed by amoxicillin+clavulanic acid 132(12.10\%) as mentioned clearly in Table 2.

Table 3 shows the most commonly prescribed antibiotic class. Penicillin (50.53\%) and the fixed-dose combination (FDC) amoxicillin+clavulanic acid was prescribed in the majority of the patients, followed by cephalosporin's (25.44\%). And Table 4, shows in the study population that the most frequent dosage form prescribed was syrups 548(50.22\%) followed by injections 212(19.43\%).

Table 5 shows the average number of drugs prescribed per prescription was 3.2. The percentage of generic drugs prescribed among 340 prescriptions was $24.11 \%$; the percentage of antibiotics and injections prescribed was $84.70 \%$ and $61.76 \%$, respectively. Similarly, the percentage of drugs prescribed from the WHO model list of essential drugs for children was found to be $88.52 \%$.

Among the 340 prescriptions, 143 potential drug-drug interactions were observed, of which $123(86.01 \%)$ prescriptions showed moderate drug-drug interaction followed by minor and major interactions, which were found to be $6.99 \%$. The detailed information on major drug-drug interaction is depicted in Table 6.

\section{DISCUSSION}

In recent years, the importance of the study on prescribing patterns has increased since it plays a key role in analysing, interpreting and improving the prescriptions and dispensing of medicines. Managing a disease with medicines constitutes an important aspect of patient care, especially in the paediatric population. ${ }^{11}$ The WHO core indicators were used to obtain the objective of this study. A total of 340 patients were included in the study and male patients were predominant (55\%) when compared to female patients (45\%) which were similar to the studies conducted by Kanish $\mathrm{R}$ et al. ${ }^{11}$ In the present study, the majority of paediatric patients belong to the age of fewer than two years (40.29\%). Similar results were found in the studies carried out by Cole CP et al. ${ }^{12}$

The most common clinical conditions were fever (27\%), followed by respiratory tract infections like upper respiratory tract infections

Table 3: Antibiotic classes prescribed in the study population.

\begin{tabular}{cccc}
\hline SL. No. & $\begin{array}{c}\text { ANTIBIOTIC } \\
\text { CLASS }\end{array}$ & FREQUENCY $(\boldsymbol{n = 2 8 3 )}$ & PERCENTAGE (\%) \\
\hline 1. & Penicillins & 143 & 50.53 \\
2. & Cephalosporins & 72 & 25.44 \\
3. & Aminoglycosides & 35 & 12.37 \\
4. & Macrolides & 30 & 10.60 \\
5. & Fluoro-quinolones & 3 & 1.06 \\
\hline
\end{tabular}

Table 4: Different dosage forms prescribed.

\begin{tabular}{|c|c|c|c|}
\hline SI. No & Dosage Form & Frequency $(n=1091)$ & Percentage (\%) \\
\hline & Injection & 212 & 19.4 \\
\hline & Tablet & 153 & 14.0 \\
\hline & Capsule & 1 & 0.1 \\
\hline & Syrup & 548 & 50.2 \\
\hline & Drops & 34 & 3.1 \\
\hline & Nebulization & 70 & 6.6 \\
\hline & Suppository & 8 & 0.7 \\
\hline & Others & 65 & 5.9 \\
\hline
\end{tabular}

(23.22\%) and lower respiratory tract infections (21\%). In a similar study, the most commonly diagnosed disease was respiratory tract infections (36.6\%), followed by fever (28.3\%).12 Out of 1091 drugs prescribed in the patient, acetaminophen 159 (14.57\%) was the commonly prescribed drug followed by antibiotics; this could be as a result of high rates of pyrexia seen in the study population. ${ }^{13}$ Similar study conducted by

Table 5: WHO core prescribing indicators results along with the recommended values.

\begin{tabular}{ccc}
\hline WHO core prescribing indicators & Observed Value & $\begin{array}{c}\text { Recommended } \\
\text { value }\end{array}$ \\
\hline $\begin{array}{c}\text { The average number of drugs } \\
\text { prescribed }\end{array}$ & 3.2 & 2 or less \\
$\begin{array}{c}\text { Percentage of drugs prescribed by } \\
\text { generic name }\end{array}$ & $24.11 \%$ & $100 \%$ \\
$\begin{array}{c}\text { Percentage of antibiotics prescribed } \\
\text { Percentage of injections prescribed }\end{array}$ & $84.70 \%$ & $20-26 \%$ \\
$\begin{array}{c}\text { Percentage of drugs prescribed from } \\
\text { the WHO model list of essential } \\
\text { drugs }\end{array}$ & $81.76 \%$ & $13.4-24 \%$ \\
\hline
\end{tabular}

Table 6: Potential Major Drug-Drug Interactions observed in the study population.

\begin{tabular}{|c|c|c|c|}
\hline Drug Class & Drugs & Severity & Possible effect \\
\hline $\begin{array}{l}\text { Serotonin } \\
\text { modulators+ } \\
\text { Antiemetics }\end{array}$ & $\begin{array}{l}\text { Phenylephrine- } \\
\text { Chlorpheniramine- } \\
\text { Dextromethorphan+ } \\
\text { Ondansetron }\end{array}$ & Major & $\begin{array}{c}\text { Increased } \\
\text { serotonergic effect of } \\
\text { dextromethorphan. }\end{array}$ \\
\hline $\begin{array}{c}\text { Diuretic+ } \\
\text { Aminoglycoside }\end{array}$ & Mannitol+ Amikacin & Major & $\begin{array}{c}\text { Mannitol may } \\
\text { increase the } \\
\text { nephrotoxic effect of } \\
\text { amikacin. Avoid use. }\end{array}$ \\
\hline $\begin{array}{l}\text { Inhalation+ } \\
\text { Anticholinergic } \\
\text { agents }\end{array}$ & $\begin{array}{l}\text { Ipratropium+ } \\
\text { Hydroxyzine }\end{array}$ & Major & $\begin{array}{l}\text { Monitor closely } \\
\text { for related } \\
\text { anticholinergic } \\
\text { toxicities (urinary } \\
\text { retention, } \\
\text { constipation, } \\
\text { tachycardia, dry } \\
\text { mouth, etc.) }\end{array}$ \\
\hline $\begin{array}{l}\text { Quinolones+ } \\
\text { Nonsteroidal anti- } \\
\text { inflammatory } \\
\text { agents }\end{array}$ & $\begin{array}{l}\text { Ciprofloxacin }+ \\
\text { Diclofenac }\end{array}$ & Major & $\begin{array}{l}\text { Increased risk of } \\
\text { seizure }\end{array}$ \\
\hline $\begin{array}{c}\text { CYP3A4 } \\
\text { substrates+ } \\
\text { CYP3A4Inducers }\end{array}$ & $\begin{array}{l}\text { Midazolam+ } \\
\text { Phenytoin }\end{array}$ & Major & $\begin{array}{l}\text { Phenytoin may } \\
\text { increase the } \\
\text { metabolism of } \\
\text { midazolam. }\end{array}$ \\
\hline $\begin{array}{c}\text { Opioid+ CNS } \\
\text { depressant }\end{array}$ & $\begin{array}{c}\text { Tramadol+ } \\
\text { Levocetirizine }\end{array}$ & Major & $\begin{array}{l}\text { CNS depressant } \\
\text { action of tramadol } \\
\text { may be enhanced. }\end{array}$ \\
\hline $\begin{array}{l}\text { Acetaminophen- } \\
\text { tramadol+ CNS } \\
\text { depressant }\end{array}$ & $\begin{array}{l}\text { Acetaminophen- } \\
\text { tramadol+ Tramadol }\end{array}$ & Major & $\begin{array}{l}\text { CNS depressant } \\
\text { effect enhanced. }\end{array}$ \\
\hline $\begin{array}{l}\text { Budesonide+ } \\
\text { CYP3A4 } \\
\text { inhibitors }\end{array}$ & $\begin{array}{l}\text { Budesonide+ } \\
\text { Clarithromycin }\end{array}$ & Major & $\begin{array}{c}\text { Budesonide } \\
\text { concentrations } \\
\text { may increase, } \\
\text { monitor closely for } \\
\text { corticosteroid excess. }\end{array}$ \\
\hline
\end{tabular}


Mathai, et al.: Drug use Pattern in Paediatric Department of a Tertiary Care Hospital

Thiruthopu et al., reported that antibiotics were one of the common class of drugs prescribed (33.33\%) in the paediatric population. ${ }^{14}$

A total of 283 antibiotics were prescribed from 5 different classes (penicillin, cephalosporin's, aminoglycosides, macrolides and quinolones). The most frequently prescribed class of antibiotics was found to be penicillin (50.53\%). Similar findings were also observed in a related study, whereas, another study reported the preponderance of cephalosporin's (50.62\%). ${ }^{15}$ Amoxicillin-Clavulanic acid (12.10\%) was the most commonly prescribed antibiotic among the penicillin class, followed by an aminoglycoside class of drug amikacin (2.93\%).

Different formulations were prescribed in the study in which syrups were the most frequently prescribed dosage form (50.2\%) followed by injections (19.43\%) which were in accordance to a study where syrups accounted for $62.73 \%$ where the authors stated that syrups can be easily administered to the paediatric population and is thus preferred. ${ }^{11}$

In the present study, the average number of drugs per encounter was found to be 3.2 which were similar to the study conducted by Karande $\mathrm{S}$ et al. ${ }^{16}$ The percentage of drugs prescribed by generics was found to be $24.11 \%$ which was much more than other studies conducted in India which reported $2.6 \%, 5.4 \%$ and $19.16 \%$ respectively. The possible reasons for poor prescription of generics could be the non-availability of the drug formulations for pediatrics. ${ }^{13,14}$ Prescribing of antibiotics in the study was found to be $84.70 \%$, which was lower compared to the studies carried out by Cole CP et al. ${ }^{12}$ and much higher than a study conducted by Farade J et al. $(28.2 \%)^{15}$ The percentage of injections prescribed was $61.76 \%$ which was higher than the recommended range of the WHO (13.4-24\%). ${ }^{17}$ Lower rates of injections were prescribed in other studies. ${ }^{11}$ Administration of medicines through injections may pose a risk for paediatrics.

In our study, the percentage of drugs prescribed from an essential drug list was found to be $88.52 \%$, which was more than the results of similar studies, which was $70.8 \%$. Ideally, all the drugs prescribed should be selected from EDL. Prescribing from the essential list will reduce irrationalities by appropriate selection of medicines and by minimizing the cost of the therapy. ${ }^{15}$

Among the prescriptions analysed, a total of 143 interactions were identified, of which most were of moderate severity $86.01 \%$, which was in accordance with the several studies and reports. ${ }^{17,18}$ Awareness about major and moderate severity drug interactions helps health care professionals to monitor and ensure safe drug use. ${ }^{10}$ The common interactions were observed between levosalbutamol+budesonide (11.8\%), followed by amikacin and ceftriaxone (9.7\%). Co-administration of the two drugs may result in nephrotoxicity and monitoring is mandatory especially when given for patients with kidney dysfunction. ${ }^{17}$

\section{CONCLUSION}

The present study assessed the prescription pattern in the paediatric population using the WHO core prescribing indicators. Fever was reported to be the most common condition followed by respiratory infections. Acetaminophen was the most frequently prescribed drug, followed by amoxicillin-clavulanic acid. It was observed that the use of antibiotics was not per WHO core indicators. Appropriateness in the use of antibiotics is to be ensured to minimize antibiotic resistance. The majority of the drug interactions observed were found to be moderate in severity, which indicates that monitoring of therapy is necessary.

\section{ACKNOWLEDGEMENT}

The authors want to thank the NGSM Institute of Pharmaceutical Sciences and Justice K.S. Hegde Charitable Hospital for their continuous support during the study.

\section{CONFLICT OF INTEREST}

Nil.

\section{ABBREVIATIONS}

WHO: World Health Organization; EDL: Essential Drug List; IEC: Institutional Ethics Committee; FDC: Fixed-dose Combination.

\section{REFERENCE}

1. Basco WT, Rimsza ME. Committee on Pediatric Work Force. Definition of a Pediatrician. AAP. 2015; 135(04):780-1.

2. Barker C, Nunn AJ, Turner S. Paediatrics: Clinical Pharmacy and Therapeutics. $5^{\text {th }}$ edition. Edinburgh: Churchill Livingstone. 2012;132-47.

3. Chandran BK, Vaddakan K, Altaf M, et al. A Retrospective study on prospective usage pattern of analgesics in orthopaedics department of a tertiary care hospital. International Journal of Scientific and Technology Research. 2020;9(03):1207-11.

4. Al-Jabari MM, Shastry CS, Chand S. Assessment of Drug Utilization pattern in Chronic Kidney Disease Patients in a Tertiary Care Hospital Based on WHO Core Drug Use Indicators. Journal of Global Pharma Technology. 2019;11(09):1-9.

5. Chand S, Shastry CS, Vinay BC, et al. Brown, white and blue bagging in special pharmacy: An emerging trend to minimize medication error. Journal of Global Pharma Technology. 2019;11(08):1-4

6. Rachana J, Shastry CS, Mateti UV et al. Incidence and associated factors of adverse drug reactions in the general medicine department of a tertiary care teaching hospital. International Journal of Pharmaceutical Research. 2019;11(03):177-84

7. Kebede HK, Gesesew HA, Goro KK, Woldehaimanot TE. Antimicrobial use in pediatric patients in a teaching hospital in Ethiopia. PLoS One. 2017:12(03):13719.

8. Roy DA, Shanfar I, Shenoy $P$ et al. Drug-related problems among chronic kidney disease patients: A pharmacist led study. International Journal of Pharmaceutical Research. 2020;12(04):79-84.

9. Gouda V, Shastry CS, Mateti UV, et al. Study on steroid utilization patterns in the general medicine department. Research J Pharm and Tech. 2019;12(10):477781.

10. Voora L, Sah SK, Bhandari R, et al. Doctor of pharmacy: Boon for healthcare system. Drug Invention Today. 2020;14(01):153-8.

11. Kanish R, Gupta K, Juneja S, et al. Prescribing pattern and pharmacy-economics of antibiotic use in the department of pediatric of a tertiary care medical college hospital in northern India. Ann Trop Med Public Health. 2015;8(04): 101-4.

12. Cole CP, James PB, Kargbo AT. An evaluation of the prescribing patterns for under-five patients at a tertiary pediatric hospital in Sierra Leone. J Basic and Clin Pharma. 2015;6(04):109-14.

13. Choudury DK, Bezbaruah BK. Antibiotic Prescriptions Pattern in Paediatric InPatient Department Gauhati Medical College and Hospital, Guwahati. Journal of Applied Pharmaceutical Science. 2013;3(08):144-8.

14. Thiruthopu NS, Mateti UV, Bairi R, et al. Drug utilization pattern in South Indian pediatric population: A prospective study. Perspect Clin Res. 2014;5(04):178-83.

15. Fadare J, Olatunya $O$, Oluwayemi $O$, et al. Drug prescribing pattern for under-fives in a pediatric clinic in South-western Nigeria. Ethiop $\mathrm{J}$ Health Sci. 2015;25(01):73-8.

16. Karande S, Sankhe P, Kulkarni M. Patterns of prescription and Drug Dispensing Indian J Pediatr. 2005;72(02):117-22

17. World Health Organization. How to investigate drug use in health facilities: Selected drug use indicators. Geneva. 1993

18. Gatechew H, Assen M, Dula F, et al. Potential drug-drug interactions in pediatric wards of Gondar University Hospital, Ethiopia: A cross-sectional study. Asian Pac J Trop Biomed. 2016:15(06):534-8. 